\title{
Effect of Potassium humate, humic acid, and compost of rice wastes in the growth and yield of two cultivars of Dill under salt stress conditions
}

\author{
Aseel K. Burhan and Duraid K.A. AL-Taey \\ Department of Horticulture, College of Agriculture, AL-Qasim Green University \\ Correspondence Author: Duraid K.A. AL-Taey, Department of Horticulture, College of Agriculture, AL-Qasim Green University \\ E-mail: duraidaltaey@gmail.com
}

Received date: 22 August 2018, Accepted date: 19 November 2018, Online date: 31 November 2018

Copyright: (C) 2018 Aseel K. Burhan and Duraid K.A. AL-Taey.2018. This is an open-access article distributed under the terms of the Creative Commons Attribution License, which permits unrestricted use, distribution, and reproduction in any medium, provid ed the original author and source are credited.

\begin{abstract}
A field experiment was conducted to determine the effect of water quality of $\left(1.2 .8 \mathrm{ds}^{-1}\right)$ as a main plot and to test two cultivars dill of Iranian and French as a sub-plot. Fertilizer mixtures from interaction of organic fertilizer and Potassium humate were used as a sub-sub-plot to study growth and yield traits, In addition, an evaluation of the tolerance level of the dill plant for salt stress was conducted for the absence of salt stress tests on the dill plant in middle and southern Iraq. The experiment was designed within the Randomized Complete Block Design (RCBD) according to the Spilt-Split Plot. The results of the study showed that the salinity of irrigation water caused a decrease in all vegetative and yield traits. The quality of fresh irrigation water was excelled in all studied traits. The results showed significant differences between the Iranian and French cultivars in some of the mentioned traits. Where the Iranian cultivar achieved the highest averages in the dry weight of the root system and the percentage of nitrogen while French cultivar has excelled in the number of leaves and total yield, Fertilizer combinations achieved significant differences, where the interaction treatment between potassium humate and rice wastes compost was significantly excelled in most vegetative traits, especially under salt stress.
\end{abstract}

Key words: Dill, Humic acid, potassium nutrition, organic composts, salt stress and dill oil

\section{INTRODUCTION}

Dill (Anethum graveolens L.), which belongs to Apiaceae family (Umbelliferae), is considered an important leafy plant for its medicinal and nutritional benefits. It is considered a medical and aromatic plant [1], it has great economic importance for being directly involved as one of the main ingredients in Drugs that repellent gases and the sedative of digestive disorders [2] where this study aims to assess the level of tolerance of two dill cultivars to salinity of irrigation water and the degree of response of these cultivars to the agriculture conditions in Iraq because it is a foreign cultivars under salt stress conditions. Areas affected by salinity are increasing and constitute $20-50 \%$ of agricultural land. Iraq suffers from agricultural areas affected by salinity, desertification for two reasons, the first is the scarcity of irrigation water, and the second is the high concentration of dissolved salts in the water of the Tigris and Euphrates rivers, which are associated with its low levels,

The accumulation of salts in the soil lead to increased osmotic pressure and food imbalance, and when using this water requires the creation of ways and means for the purpose of successful use without the adverse impact of land productivity and environmental pollution [22]. Organic fertilizer plays an important role in increasing soil fertility, improving its physical and chemical properties, and increasing nutrient elements availability, especially micronutrient elements, where it works to provide the elements directly and indirectly by release non-availability elements in soil by adjusting soil pH. Organic fertilization is the most important way to develop and raising the agricultural production value and reduce the environmental pollution resulting from the excessive use of mineral fertilizers. The nutrients balance in the soil and meet the basic requirements of plant nutrient elements throughout the growth stages. It also reduces the intensive needs of mineral fertilizers, Reduce the loss of nutrient elements forms, the organic fertilization can behave as a slow releasing material for nutrients to the soil and achieving the nutrients equilibrium after the end of plant growth for subsequent seasons [17]. 
Humic acid considered an important organic fertilizer, which used to improve the properties of soil and speed up growth. Humate is considered the most common material that increases the nutrient elements, especially the micronutrient elements [3]. Therefore, the study aims to reduce the effect of salt stress on the growth and yield of the dill using organic fertilizer and potassium humate, and to maximize the use of the drainage water with the applying of a good management system for irrigation.

\section{MATERIALS AND METHODS}

The soil of the land was prepared by plowing it with the moldboard plow, settled and divided it into three replicates. The distance between the replicate and other is $1 \mathrm{~m}$, each replicate included 20 plot (experimental unit) with dimensions: a width of $2 \mathrm{~m}$ and a length of $1 \mathrm{~m}$ for each plot and leaving a distance of $1 / 2 \mathrm{~m}$ between plot and other for service operations. Seeds were cultivated directly in the field on 10/10/2017 in lines, with rate of ten lines in each experimental unit. The distance between them is $10 \mathrm{~cm}$, three seeds were cultivated in one pit and after germination on 21/10/2011, the thinning process on the plant was conducted after the emergence of the two real leaves. The number of plants was 200 plants in one experimental unit and the service operations were conducted for crop such as Grubbing and weeding whenever needed. A sample of soil was taken for chemical and physical analysis as shown in Table (1).

Table 1: Some chemical and physical traits of soil

\begin{tabular}{|c|c|c|}
\hline Traits & Units & Value \\
\hline Soil texture & & \\
\hline Clay & \multirow{3}{*}{ g. $\mathrm{kg}^{-1}$} & 32.5 \\
\hline Sand & & 27 \\
\hline Silt & & 40.5 \\
\hline $\mathrm{pH}$ & & 7.03 \\
\hline Electrical conduction EC & Ds.m ${ }^{-1}$ & 2.93 \\
\hline $\mathrm{NaCl} \%$ & & $9.5 \%$ \\
\hline $\mathrm{CO}_{3}{ }^{-2}$ & & Nill \\
\hline $\mathrm{HCO}_{3}^{-}$ & \multirow{6}{*}{ mmol. $\mathrm{L}^{-1}$} & 18.5 \\
\hline $\mathrm{Ca}^{+2}$ & & 9.2 \\
\hline $\mathrm{Mg}^{+2}$ & & 24.25 \\
\hline $\mathrm{K}^{+}$ & & 0.876 \\
\hline $\mathrm{Na}^{+}$ & & 11.87 \\
\hline $\mathrm{SO}_{4}^{-2}$ & & 8.25 \\
\hline Organic matter & & 1.5 \\
\hline
\end{tabular}

The experiment was conducted according to the Spilt-Split Plot within the Randomized Complete Block Design (RCBD), with three replicates in each replicate was 20 treatments. The main plot represented the two types of water: fresh water and drainage water (W.Q2, W.Q1) respectively, and the Sub Plot, which included the testing of two cultivars of the dill plant, namely, Iranian and French, which is symbolized by $(\mathrm{C} 1, \mathrm{C} 2)$ respectively, while the Sub-Sub-Plot included the added fertilizers to the soil listed below:

T1: without adding which is symbolized

T2: Potassium humate $\left(2 \mathrm{~kg}\right.$. ha $\left.{ }^{-1}\right)+$ rice wastes compost $\left(20\right.$ tons. ha $\left.{ }^{-1}\right)$, which is symbolized

T3: Humic acid (20 kg.100 $\left.\mathrm{m}^{-2}\right)$, which is symbolized

T4: Rice wastes compost (20 tons. $\left.\mathrm{ha}^{-1}\right)$, which is symbolized

T5: Humic acid $\left(20 \mathrm{Kg} .100 \mathrm{~m}^{-2}\right)+$ Rice wastes compost $\left(20\right.$ tons. ha $\left.{ }^{-1}\right)$, which is symbolized

The experiment included 60 experimental units (plot), and the differences between the averages were tested according to the least significant difference (L.S.D) at the probability level of 0.05 [4].

Table 2: Physical and chemical traits of rice wastes compost.

\begin{tabular}{|c|c|c|c|}
\hline Traits & Value & Traits & Value \\
\hline $\mathrm{EC}\left(\mathrm{ds} . \mathrm{m}^{-1}\right)$ & 0.93 & $\mathrm{~K}(\%)$ & 0.260 \\
\hline $\mathrm{PH}$ & 6.50 & $\mathrm{Ca}(\%)$ & 1.30 \\
\hline $\mathrm{C}(\%)$ & 44.6 & $\mathrm{Mg}(\%)$ & 0.38 \\
\hline $\mathrm{N}(\%)$ & 2.48 & $\mathrm{Na}(\%)$ & 0.430 \\
\hline $\mathrm{C} / \mathrm{N}$ & 18.0 & $\mathrm{Fe}(\%)$ & 0.259 \\
\hline $\mathrm{P}(\%)$ & 0.540 & $\mathrm{Zn}(\%)$ & 0.031 \\
\hline $\mathrm{Mn}(\%)$ & 0.011 & Humidity (\%) & $35-30$ \\
\hline
\end{tabular}

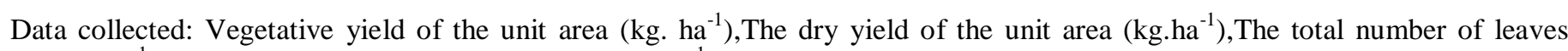
(leaf.plant $\mathrm{t}^{-1}$ ),Plant content of total chlorophyll ( $\mathrm{mg} 100 \mathrm{~g}^{-1}$ fresh weight): it is calculated by Spectrophotometer on $668 \mathrm{~nm}$ and 645 $\mathrm{nm}$ wavelengths [5]. Percentage of nitrogen ( $\mathrm{mg}^{-1} \mathrm{~g}^{-1}$ dry weight): it is calculated by using Kjedahl method [6]. Percentage of 
phosphorus (mg. $\mathrm{g}^{-1}$ dry weight): It is measured using a spectrophotometer spectroscopy at a wavelength of $410 \mathrm{~nm}$ [7]. Finally, Percentage of potassium and sodium (mg. $\mathrm{g}^{-1}$ dry weight): It is measured using the Flame photometer.

\section{RESULTS AND DISCUSSION}

\section{Vegetative yield of unit area $\left(\mathrm{kg} \mathrm{ha}^{-1}\right)$}

Table (3) shows significant differences in vegetative yield when irrigated with different types of water. Where the treatments irrigated with fresh water achieved the highest average amounted of $\left(7938 \mathrm{~kg}\right.$. ha $\left.{ }^{-1}\right)$ compared to the treatments irrigated with drainage water (saline water), which recorded the lowest average amounted of $\left(5530 \mathrm{~kg}^{\text {. ha }}{ }^{-1}\right)$. The results also showed significant differences between the two cultivars, where the French cultivar significantly recorded the highest average reached of $(7311 \mathrm{~kg}$.

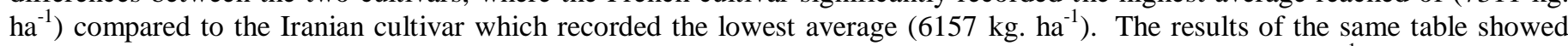
significant differences between fertilizer combinations, where T2 achieved the highest average of $\left(7292 \mathrm{~kg}^{-1} \mathrm{ha}^{-1}\right) \mathrm{compared}$ to the control treatment which recorded the lowest average of $\left(5425 \mathrm{~kg}_{\text {. ha }}^{-1}\right)$. Table (4) shows there is a significant difference for the triple interaction between the two treatments, where C2T2 treatment gave the highest average of $\left(10015 \mathrm{~kg}^{\left.-\mathrm{ha}^{-1}\right)} \mathrm{irrigated}\right.$ with fresh water. As for irrigation with drainage water, the treatment C2T3 gave the highest average of $\left(6850 \mathrm{~kg}\right.$. ha $\left.{ }^{-1}\right) \mathrm{compared} \mathrm{to} \mathrm{the}^{-1}$ control treatment.

\section{The dry yield of the unit area $\left(\mathrm{kg} \mathrm{ha}^{-1}\right)$}

Table (3) shows significant differences in the dry yield when irrigating with two different types of irrigation water. Where

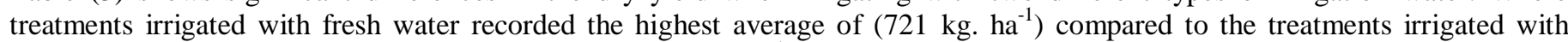
saline water, which recorded the lowest average of $\left(506 \mathrm{~kg}^{-1} \mathrm{ha}^{-1}\right)$. It was not observed significant differences between the Iranian and French cultivars. The results of the same table indicate significant differences between fertilizer combinations, where T2 treatments achieved the highest average of $\left(667 \mathrm{~kg}\right.$. ha $\left.{ }^{-1}\right)$ compared to the $\mathrm{T} 1$ control treatment, which recorded the lowest average of $\left(475 \mathrm{~kg} . \mathrm{ha}^{-1}\right)$. The results of Table (4) indicate that the triple interactions have significant differences. The treatments of $(\mathrm{C} 2 \mathrm{~T} 5$, C2T2) with fresh water gave the highest average of $\left(167.7,164.7 \mathrm{~kg}\right.$. ha $\left.{ }^{-1}\right)$, respectively, compared to WQ2C1T1 treatment, which recorded the lowest average was $\left(62.7 \mathrm{~kg} . \mathrm{ha}^{-1}\right)$.

\section{Number of leaves (leaves. plant ${ }^{-1}$ )}

Table (3) indicates that there are significant differences in the number of leaves when irrigated with two different types of irrigation water. Where the treatments irrigated with fresh water were significantly excelled by giving it the highest average of (10.45 leaves. plant $\left.{ }^{-1}\right)$ compared to treatments irrigated with salty drainage water, which recorded the lowest average of (8.59 leaves. plant $\left.{ }^{-1}\right)$. It is also observed there was a significant difference between the two cultivars, where the French cultivar has significantly excelled by giving it the highest average of ( 9.95 leaves. plant $\left.{ }^{-1}\right)$ compared to the Iranian cultivar which recorded the lowest average of $\left(9.09\right.$ leaves. plant $\left.{ }^{-1}\right)$. The results of the same countries indicate that there are significant differences between fertilizer combinations, where T4 treatment recorded the highest average of (10.23 leaves. plant $\left.{ }^{-1}\right)$ compared to the control treatment (T1), which recorded the lowest average of (8.32 leaves. plant $\left.{ }^{-1}\right)$. It is noted in the triple interaction between the studied factors in Table (4), the significant superiority of the C2T2 treatment, which amounted to (11.73 leaves.plant-1), This is in the case of irrigation with fresh water, but in the case of irrigation with salty drainage water, it is observed the excelling of C2T4 treatment by giving it the highest average of (10.07 leaves.plant $\left.{ }^{-1}\right)$ compared to the control treatment, which gave the lowest average of $\left(6.73\right.$ leaves.plant $\left.{ }^{-1}\right)$.

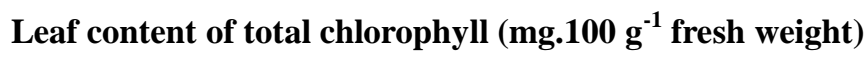

Table (3) shows that there are significant differences in the leaves content of total chlorophyll between the two types of irrigation water. Irrigated treatments with fresh water achieved the highest average amounted of $\left(74.11 \mathrm{mg} .100 \mathrm{~g}^{-1}\right.$ fresh weight $)$ compared to the treatment irrigated with irrigation with drainage water which gave the lowest average of $\left(69.24 \mathrm{mg}_{100} \mathrm{~g}^{-1}\right.$ fresh weight). The treatment between the two cultivars did not record significant differences. A significant difference was observed between fertilizer combinations. The treatment T5 was significantly excelled by recording it the highest average of $\left(76.72 \mathrm{mg} .100 \mathrm{~g}^{-1}\right.$ fresh weight) compared to the control treatment (T1), which recorded the lowest average of (63.71 mg.100 $\mathrm{g}^{-1}$ fresh weight). Table (4) shows that the triple interactions have significant differences. The C2T5 and C1T5 treatments when irrigated with fresh water recorded the highest average amounted of $\left(80.53,80.00 \mathrm{mg} .100 \mathrm{~g} \mathrm{~g}^{-1}\right.$ fresh weight). In addition, when irrigated with drainage water, the C1T5 treatment gave the highest average of $\left(73.75 \mathrm{mg} .100 \mathrm{~g}^{-1}\right.$ fresh weight) compared to the C2T1 treatment which gave the lowest average of (59.67 mg. $100 \mathrm{~g}^{-1}$ fresh weight).

\section{Nitrogen \%}

Table (3) shows significant differences between the treatments when irrigation with two qualities of irrigation water. The treatment irrigated with fresh water were significantly excelled with $3.301 \%$ compared to the irrigated water, which gave the lowest average of $(2.859 \%)$. It was also found that there were significant differences between the two cultivars, where the Iranian cultivar was significantly excelled by giving it the highest average amounted of (3.219\%) compared to the French cultivar, which recorded a lowest average of $(2.941 \%)$, the treatments in the combinations of fertilizer did not record significant differences. 
Citation: Aseel K. Burhan and Duraid K.A. AL-Taey, 2018. Design of CMOS Architecture for Small Signal Acquisition Advances in Natural and Applied Sciences., 12(11): 1-6. DOI: 10.22587/anas.2018.12.11.1

Table (4) shows significant differences in the triple interaction treatments. The C1T2 treatment, which irrigated with drainage water, recorded the highest average of (3.943\%), without significant differences from C1T3 and C2T4 treatments that irrigated with fresh water by giving it an average of $(3.759 \%, 3.621 \%)$, respectively.

\section{Phosphorus\%}

Table (3) indicates significant differences between the two types of irrigation water. The irrigated treatments with fresh water were significantly excelled giving it the higher average of $(0.540 \%)$ compared to treatments irrigated with drainage water, which gave the lowest average of $(0.372 \%)$. No significant differences were observed between the two cultivars. There were also no significant differences between fertilizer combinations. Table (4) shows that the triple interactions had significant differences between the treatments. Where the C1T2 and C1T5 treatments irrigated with fresh water gave the highest average $(0.603 \%$, $0.602 \%)$, respectively, compared to $\mathrm{C} 2 \mathrm{~T} 3$ treatment irrigated with drainage water

\section{Potassium\%}

Table (3) shows significant differences in the percentage of potassium when irrigating with two types of irrigation water. The irrigated treatments with fresh water were significantly excelled by giving it the higher average of $4.624 \%$ compared to treatments irrigated with salty drainage water, which gave the lowest average of $4.179 \%$. No significant differences were observed between the two cultivars. The treatments between the fertilizer combinations showed significant differences where the T2 gave the highest average of $(4.565 \%)$ compared to the control treatment (T1) which gave the lowest average of $4.202 \%$. The results of the triple interaction of Table (4) showed significant differences between the two treatments. The C2T5 and C2T2 treatments irrigated with fresh water by giving it the highest average $(5.021 \%, 5.158 \%)$, respectively compared to the control treatment (C2T1), irrigated with salty drainage water which gave an average amounted of $(3.483 \%)$.

\section{Sodium\%}

Table (3) shows significant differences in the percentage of sodium in the leaves when irrigated with two different types of irrigation water. It was observed there was a significant increase in the percentage of sodium when irrigated with salt water through giving it the highest average amounted of (1.960\%) compared to the treatment irrigated with fresh water which recorded the lowest average of (1.404\%). From the same table, the average percentage of sodium in leaves decreased in the Iranian cultivar by recording it the lowest average of $1.357 \%$ compared to the French cultivar, which recorded the highest average of $2.007 \%$. The results of the same table indicate significant differences between fertilizer combinations. The T4 treatment recorded the lowest average of $1.503 \%$ compared with the T1 treatment, which recorded the highest average of $1.920 \%$. In the triple interaction, Table (4) showed that the percentage of sodium in leaves when irrigated with fresh water was decreased at C1T3 treatment (1.125\%) compared to $\mathrm{C} 2 \mathrm{~T} 1$ by giving it an average of $(1.875 \%)$. When irrigating with drainage water ( $8 \mathrm{ds} . \mathrm{m}-1)$, it was observed there was an increase in the percentage of sodium in $\mathrm{C} 2$ cultivar compared to $\mathrm{C} 1$ cultivar when using the same fertilizers combinations ( $\mathrm{T}$ ).

Table 3: Effect of the quality of irrigation Water, cultivar and Organic Fertilizers and their Interaction in the traits of Vegetative and Qualitative.

\begin{tabular}{|c|c|c|c|c|c|c|c|c|}
\hline Treatments & Vegetative yield & Dry yield & Number of leaves & Chlorophyll & N\% & P\% & K\% & Na\% \\
\hline WQ1 & 7938 & 721 & 10.45 & 74.11 & 3.301 & 0.540 & 4.624 & 1.404 \\
\hline WQ2 & 5530 & 506 & 8.59 & 69.24 & 2.859 & 0.372 & 4.179 & 1.960 \\
\hline LSD (0.05) & 1219.2 & 202.9 & 1.337 & 3.505 & 0.3707 & 0.1255 & 0.4245 & 0.3513 \\
\hline CV1 & 6157 & 587 & 9.09 & 72.47 & 3.219 & 0.498 & 4.290 & 1.357 \\
\hline CV2 & 7311 & 640 & 9.95 & 70.89 & 2.941 & 0.414 & 4.513 & 2.007 \\
\hline LSD (0.05) & 975.3 & N.S & 0.483 & N.S & 0.2660 & N.S & N.S & 0.2872 \\
\hline T1 & 5425 & 475 & 8.32 & 63.71 & 2.959 & 0.434 & 4.202 & 1.920 \\
\hline T2 & 7292 & 667 & 10.13 & 74.01 & 3.219 & 0.468 & 4.565 & 1.644 \\
\hline T3 & 7117 & 649 & 9.83 & 72.55 & 3.028 & 0.440 & 4.371 & 1.668 \\
\hline T4 & 6942 & 637 & 10.23 & 71.40 & 3.105 & 0.490 & 4.379 & 1.503 \\
\hline T5 & 6896 & 640 & 9.10 & 76.72 & 3.090 & 0.447 & 4.491 & 1.676 \\
\hline LSD $(0.05)$ & 894.9 & 93.5 & 0.719 & 3.311 & N.S & N.S & 0.3312 & 0.2809 \\
\hline
\end{tabular}

Table 4: Triple interaction to the effect of the quality of irrigation water, cultivar and fertilization in the traits of Vegetative and Qualitative.

\begin{tabular}{|c|c|c|c|c|c|c|c|c|}
\hline Treatments & Vegetative yield & Dry yield & Number of leaves & Chlorophyll & N\% & P\% & K\% & Na\% \\
\hline W1C1T1 & 7350 & 636 & 8.53 & 64.39 & 2.931 & 0.543 & 4.325 & 1.225 \\
\hline W1C1T2 & 6650 & 704 & 11.13 & 76.50 & 3.113 & 0.602 & 4.581 & 1.242 \\
\hline W1C1T3 & 7350 & 685 & 11.07 & 74.58 & 3.621 & 0.600 & 4.300 & 1.125 \\
\hline W1C1T4 & 6533 & 675 & 10.73 & 75.83 & 3.542 & 0.571 & 4.492 & 1.325 \\
\hline
\end{tabular}


Citation: Aseel K. Burhan and Duraid K.A. AL-Taey, 2018. Design of CMOS Architecture for Small Signal Acquisition Advances in Natural and Applied Sciences., 12(11): 1-6. DOI: 10.22587/anas.2018.12.11.1

\begin{tabular}{|c|c|c|c|c|c|c|c|c|}
\hline W1C1T5 & 7400 & 712 & 9.73 & 80.53 & 3.047 & 0.603 & 4.200 & 1.233 \\
\hline W1C2T1 & 6515 & 593 & 9.47 & 69.53 & 3.271 & 0.516 & 4.675 & 1.829 \\
\hline W1C2T2 & 10015 & 838 & 11.73 & 75.10 & 3.271 & 0.446 & 5.021 & 1.529 \\
\hline W1C2T3 & 8600 & 765 & 10.87 & 73.33 & 3.087 & 0.452 & 4.982 & 1.629 \\
\hline W1C2T4 & 9950 & 775 & 11.60 & 71.33 & 3.759 & 0.555 & 4.507 & 1.315 \\
\hline W1C2T5 & 9017 & 823 & 9.67 & 80.00 & 3.367 & 0.412 & 5.158 & 1.537 \\
\hline W2C1T1 & 3667 & 313 & 6.73 & 61.25 & 2.884 & 0.351 & 4.325 & 1.625 \\
\hline W2C1T2 & 6203 & 580 & 8.73 & 72.02 & 3.943 & 0.496 & 4.337 & 1.517 \\
\hline W2C1T3 & 5667 & 522 & 8.00 & 72.56 & 3.127 & 0.414 & 3.996 & 1.737 \\
\hline W2C1T4 & 5083 & 495 & 8.53 & 73.26 & 2.616 & 0.465 & 4.187 & 1.258 \\
\hline W2C1T5 & 5667 & 547 & 7.73 & 73.75 & 3.369 & 0.330 & 4.154 & 1.387 \\
\hline W2C2T1 & 4167 & 357 & 8.53 & 59.67 & 2.751 & 0.327 & 3.483 & 2.954 \\
\hline W2C2T2 & 6300 & 543 & 8.93 & 72.42 & 2.548 & 0.328 & 4.321 & 2.287 \\
\hline W2C2T3 & 6850 & 625 & 9.40 & 69.73 & 2.277 & 0.293 & 4.208 & 1.179 \\
\hline W2C2T4 & 6200 & 602 & 10.07 & 65.17 & 2.501 & 0.369 & 4.329 & 2.112 \\
\hline W2C2T5 & 5500 & 480 & 9.27 & 72.59 & 2.276 & 0.343 & 4.450 & 2.646 \\
\hline LSD(0.05) & 1838.8 & 210.7 & 1.484 & 6.448 & 0.7004 & 0.2252 & 0.6484 & 0.5668 \\
\hline
\end{tabular}

The results showed that there was a significant decrease in the studied traits in saline water compared to the irrigation with fresh water. This may be due to the effect of osmosis resulted from increasing salts in soil. Increasing the level of osmosis in the solution leads to a decrease in the water osmotic pressure and thus obstruct water absorption by the roots of the plant, as well as the reason may be due to the accumulation of sodium ions and chloride to the toxic limit, leading to a lack of the activity of Meristematic tissue and Inhibition of cell division and elongation [11]. As well as the lack of water absorption due to the osmosis effect lead to the entry of nutrient elements, which negatively affects the cellular metabolism and the biological events within the cell affecting the major effectiveness such as photosynthesis and respiration[9,21] ,This what confirmed by[10,8] that the main negative effects of salinity are increasing the production of Reactive oxygen species (ROS), which causes Disruption of cell metabolism, oxidation of some internal structures of cell components such as the cellular wall, and reducing the volume of internal stroma Which affect the work of chlorophyll. The cultivars achieved significant differences in Vegetative yield of the unit area, the number of leaves and the percentage of nitrogen and sodium, This may be due to the genetic differences between cultivars resulted from variation of genetic Factors and responsible for traits of vegetative growth, may be due to the genetic behavior of cultivars vary due to the percentage of food changes in the plant from the base substance, which are carbohydrates, and this behavior is largely influenced by environmental conditions[12]. The organic superiority of the vegetative and dry yield, the number of leaves, the percentages of potassium, sodium, and the proline content when adding organic fertilizers indicate that the organic matter provide and availability of nutrient elements for the plant by increasing the cation exchange surfaces and improving soil permeability. Organic acids also increase holding water availability [13] These results agree with [14] in increase the traits of vegetative growth significantly when treated with the humic acid on the Coriander plant. The reason for the significant superiority of the irrigated treatments with fresh water in the percentage of nitrogen, phosphorus and potassium compared to the irrigated treatments with salty drainage water may be due to the negative effect of salinity on nitrogen uptake through direct competition between $\mathrm{Cl}^{-}$and $\mathrm{NO}_{3}{ }^{-}$and the absorption of nitrates or indirect competition by changing properties of transmissibility of plasma membranes by influencing on proteins membrane[15,19]. The decrease in the percentage of phosphorus may be explained by the competition between $\mathrm{Cl}^{-}$and $\mathrm{H}_{2} \mathrm{PO}_{4}{ }^{-}$, where $\mathrm{Cl}^{-}$reduces the absorption of $\mathrm{H}_{2} \mathrm{PO}_{4}$ by the plant [16]. The reason for the decrease in the percentage of potassium in the leaves is due to the inverse relationship between it and the sodium concentration, where the irrigation with saline leads to an increase in the concentration of sodium in the soil solution, which causes the removal of potassium from the absorption area in the roots as well as disruption in the nutrient balance and reduce its absorption [17,18]. [19] have shown that sodium accumulates rapidly in cells under saline conditions due to disabling the mechanism of Optional permeability for the plasma membrane. The accumulation may also be because the sodium is absorbed free of charge and without the consumption of energy and its properties by moving quickly within the plant to the leaves. [20] Mentioned that when Organic matter is added, the percentage of sodium decreases because a part of the sodium is reserved by organic matter in the form of Na-Organic compound.

\section{CONCLUSION}

1- The previous results proved impact reduction on dill growth and yield by saline water compare with river water in vegetative yield, dry yield, number of leaves, chlorophyll ,N\%,P\%,K\% and $\mathrm{Na} \%$ in leaves

2- There is different response between the study cultivars the CV1 achieved highest values in some traits while the CVs2 achieved highest values in some traits.

3- The humic acid and potassium humate and rice compost was alleviated the negative effect of saline water and increased the growth in normal status

\section{REFERENCES}


[1] Kaur G.J. and Arora D.S. Bioactive potential of Anethumgraveolens, Foeniculum vulgare and Trachyspermumammi belonging to the family Umbelliferae - Current status.J. Med. Plants Res., 4(2):87-94, 2010.

[2] Said- Al Ahl H.A.H, Sarhan A.M.Z, Abou Dahab A.D.M, AbouZeid E.N, Ali M.S. and Naguib N.Y. Volatile oil composition of Anethum graveolens affected by harvest stage.International Journal of Plant Science and Ecology 1(3):93-97, 2015.

[3] Lutzow M.V, I. Koegel, E Eckschmitt and E. Matzne. Stabilization of organic matter in temperate soils mechanism and their relevance under different soil condition-areview, Eur. Soil. Sci., 57: 426-445, 2006.

[4] Al-Rawi, Khasha Mahmood and Abdul Aziz Khalaf Allah. Design and Analysis of Agricultural Experiments, Mosul University, Ministry of Higher Education and Scientific Research, Republic of Iraq, 2000.

[5] Goodwin, T.W. Chemistry \&Biochemistray of Plant Pigment .2nd Academic .Prss. London. New York. San Francisco: 373, 1976.

[6] Jackson W. Humic, Fulvic and Microbial Balance: Organic Soil Conditioning, 329. Evergreen, Colorado: Jackson Research Center. (USA), 1993.

[7] John Ryan, George Stephan and Abdul Rashid. Soil and Plant Analysis, Laboratory Manual, International Center for Agricultural Research in the Dry Areas ICARDA, Aleppo, Syria, 2003.

[8] Al-Taey, D. K.A., Mijwel A. K., Al-Azawy S.S. Study efficiency of poultry litter and kinetin in reduced effects of saline water in Vicia faba. Research J. Pharm. and Tech. 2018; 11(1):294-300, 2018.

[9] Al-Taey, D.K.A., S.S.M. AlAzawi and M.H..Husien. Effect of Spraying Acetyl Salicylic Acid on the Plant Tolerance for Salt Stress \& Survival Percentage after Transplanting of Orange (Citrus sinensis). Babylon journal university -Pure and Applied science; 18(4):1513-1520, 2010.

[10] Eraslan, F., A., Inal, D.J Pilbeam and A. Gunes. Interactive effects of salicylic acid and silicon on oxidative damage and antioxidant activity in spinach (Spinacia oleracea L. cv. Matador) grown under boron toxicity and salinity. Plant Growth Regul, 55:207-219, 2008;.

[11] AL-Taey, D.K.A., S. S. M. AL-Azawi., M. J. H. AL-Shareefi and A.R. AL-Tawaha. Effect of saline water, NPK and organic fertilizers on soil properties and growth, antioxidant enzymes in leaves and yield of lettuce (Lactuca sativa var. Parris Island) Res. on Crops 19 (3):441-449, 2018.

[12] Sajit, Farhan Kadhim. Effect of organic manure and Cutting dates on the growth and yield of two cultivars of anthhenum graveolens L. Master Thesis. University of Kufa . College of Agriculture, 2013.

[13] Murphy B.W. Impact of soil organic matter on soil properties-a review with emphasis on Australian soils. Soil Res. 53; 605-635, 2015.

[14] Al-Attabi, Bida' Rachid Helou. Effect of Salicylic acid, Hiumc acid, phosphorus and zinc elements in the growth and yield of volatile oil and its components in coriander plant ( coriandrum sativum L.). PhD thesis. Baghdad University . College of Agriculture, 2018.

[15] Meloni, D.A., Gulotta, M.R., Martinez, C.A and M.A.Oliva. The effects of salt sress on growth, nitrate reduction and proline and glycinebetaine accumulation in Prosopis alba. Braz. J. Plant Physiol. 16(1):39-46, 2004.

[16] Pessarakli, M. Hand Book of Plant of Crop Stress. Second Edition, University of Arizona. U.S.A, 1999.

[17] Al-Taey, D. K. A., Z. Z. Majid. THE ACTIVITY OF ANTIOXIDANTS ENZYMES AND NPK CONTENTS AS AFFECTED BY WATER QAULITY, KINETIN, BIO AND ORGANIC FERTILIZATION IN LETTUCE (Lactuca sativa L.). Iraqi Journal of Agricultural Sciences: 49(3):506- 518, 2018.

[18] Khan, A., Syeed, S., Masood, A., Nasar, R. and N. Iqpal. Application of salicylic acid increases contents of nutrients and antioxidative metabolism in Mung Bean and alleviates adverse effects of salinity stress. International Journal of Plant Biology, 1:1-8, 2010.

[19] AL-Taey, D. K. A. and A.H. Saadoon. Effect of treatment of Salicylic acid and water Salinity on the Growth and Nitrate Accumulation with nitrate reductase activity in the Leaves of Spinach, Spenacia oleracea L. Journal of Babylon University, Pure and Applied Sciences, 3(22):1188-1203, 2014.

[20] Stevenson, F.j Humus Chemistry . Genesis, Compositions, Reactions. $2^{\text {nd }}$ Ed. NY: Wiley and Sons Inc, 1-25, 1982.

[21] Golezani K.G, S.Z. Salmasi, S. Dastborhan. Changes in essential oil content of dill (Anethum graveolens) organs under salinity stress. Journal of Medicinal Plants Research; 5(14), p: 3142-3145, 2011.

[22] Al-Azawi S.S.M. Effect of Water Quality and Kinetin Treatment on Growth and Catalase Activity of Maize Seedlings (Zea mays L.). Journal of Babylon University Pure and Applied Sciences, 4 (23):1667-1685, 2015. 